\title{
The Moon: in Prehistoric Lunisolar Rock Calendar "Quesera"-Cheeseboard- at Lanzarote, Canary Islands, Spain
}

\author{
Marcial Medina ${ }^{+}$, Antonio Arnaiz-Villena \\ Department of Inmunology, University Complutense, School of Medicine, 28040 Madrid, Spain. \\ *Corresponding Author: Antonio Arnaiz-Villena. Departamento de Inmunologia, Facultad de Medicina, Universidad \\ Complutense, Pabellón 5, planta 4. Avd. Complutense s/n, 28040, Spain. E-mail: arnaizantonio@gmail.com \& \\ aarnaiz@med.ucm.es; Web page: http://chopo.pntic.mec.es/biolmol/
}

(Received 1 April 2018; Accepted 25 April 2018; Published 5 September 2018)

\begin{abstract}
This present paper is an integral part of another paper which completes the work (Int. J. Mod. Anthrop., 2018, 2:147-161). This part is about Moonrise observations and calculations which have been found from Cheeseboard/"Quesera" monument at Lanzarote Island in Zonzamas archaeological area in Canary Islands (Spain). This present paper shows that both a Sun calendar and a Moon calendar adjusted to fit into 29 or 30 solar days months are represented within this Lanzarote prehistoric monument. Age of built is not calculated by absolute methods, but other archaeological items throughout Lanzarote have been dated by $\mathrm{C} 14$, between $2 \mathrm{nd} / 1 \mathrm{st}$ millennium BC. Genetic, cultural Atlantic and Mediterranean Megalithism and other archaeological / cultural traits suggest that this Cheeseboard/"Quesera" may be included in a Megalithic/Bronze Age context which may not be coincidental with this Age in other areas. However, megalithic findings in other Macaronesia Islands (Azores, Madeira, Selvagens) strongly suggest that Canary Islands may also have megalithic culture artifacts. It is possible that people massive emigration that occurred after Sahara desiccation may have also reached Canary Islands in addition to Western Europe and other areas and they may be related to these monument builders. Rock carved strips and ridges, "car-ruts" (megalithic in Malta) which occur in Azores, Lanzarote, Malta Islands, Turkey, Iberia and other World areas, supports a common and ancient culture origin. In any case, builders are more ancient than those who may have received Punic or Roman influence.
\end{abstract}

Keywords: Zonzamas, Quesera, Lanzarote, Canary Islands, Anthropology, Prehistory, Genetics, Iberian Scripts, Calendar, Lunisolar, Sun, Moon, Achano, Archaeology, Berber, Lybic, Scripts, Roman, Latin, Punic, Car-ruts, Majos, Guanches, Majos 


\section{Introduction}

Canary Islands peopling is still unclear. Several hypotheses have been considered. North Africans, Mediterraneans, Atlantic Europeans seem all to have contributed to ancient Canarians or "Guanches" peopling (Arnaiz-Villena et al., 2015). North African and Iberian genes have been exchanged since prehistoric times (Arnaiz-Villena et al., 1999, 2001, 2002). Thus, genetic differences between Western Mediterraneans and North West Africans are scanty (Arnaiz-Villena et al., 2015, 2017; Hajjej et al., 2018) because prehistoric Atlantic Europe, North African and Canary Islands belong to related cultural and genetic group (Arnaiz-Villena et al., 2017). Also, Canarian prehistory should in part be interpreted in the context of Megalithic Atlantic culture (ArnaizVillena et al., 2015, 2017; Medina \& Arnaiz-Villena, 2018). In addition, a lunisolar calendar has been found in Lanzarote Island, Canary Is, "La Quesera"/Cheeseboard of Zonzamas (Medina and Arnaiz-Villena, 2018); volcanic Canary Islands (Spain) are placed in front of Moroccan Coast (Figs 1, 2)

Prehistoric Atlantic petroglyphs, mummifications, pyramids and possible megalithic buildings have been found (Medina and Arnaiz-Villena, 2018), particularly this lunisolar calendar "Cheeseboard" of Zonzamas in Lanzarote Island. However, archaeological dating based on absolute objective methods are greatly lacking in Canary Islands archaeological patrimony (Atoche Peña \& Ramirez Rodriguez, 2009).

Moon is easily seen from Earth and their phases are known for most people (Fig. 1). Paleolithic lunar calendars have been recorded, however lunar calendars soon had to accommodate to a solar calendar to explain seasonal variations (solar calendar) for time recording and practical use, like in agriculture or cattle birth handling. Also, for keeping a permanent time registry (Barrios-Garcia, 2004). Lunar phases are evident and easy to observe. Canarians had also a lunar calendar which is also represented in "Quesera"/Cheeseboard of Zonzamas (Lanzarote) Lunisolar calendar (Medina and Arnaiz-Villena, 2018). A synodic month is the time that full Moon complete an around to Earth with respect to Sun (29.5 solar days). Synodic lunar calendar is a calendar used in order to synchronize lunar and solar calendar: the path of Moon with respect to Sun (synodic month). In this calendar, 12 synodic months are counted (by convention 29 or 30 days are used instead of 29.5); a total of 354.36 days for a year are obtained, which is different from sidereal Moon month which lasts 27.3 days and does not take into a count that Moon is rotating around another rotating body (Earth) and thus Moon travels 
more than $360^{\circ}$ each cycle. Moon goes through four phases during this month: as the Moon orbits around the Earth. The half of the Moon that faces the Sun will be lit up. The different shapes of the lit portion of the Moon that faces the Sun will be seen. Three different shapes of the lit portion of the Moon can be seen from Earth and they are known as phases of the Moon (Fig. 1). Each phase repeats every 29.53 days. The same half of the Moon always faces the Earth so the phases will always occur over the same half of the Moon surface. A phase is an angle of the Moon to Earth so it appears differently every day (Barrios-García, 2004; Magli, 2016).

Therefore, man has used lunar measure of time by taking Moon phases and months early in societies, giving a particular importance to full Moon phase (Fig. 2). In the present paper, we describe how a lunar calendar is interrelated with a solar calendar (previously described) in "Quesera"/Cheeseboard of Zonzamas Lanzarote Island monument (Figs 1, 3); its builders must likely belong to a megalithic Atlantic culture which is the main character of this monument (Medina \& Arnaiz-Villena, 2018).
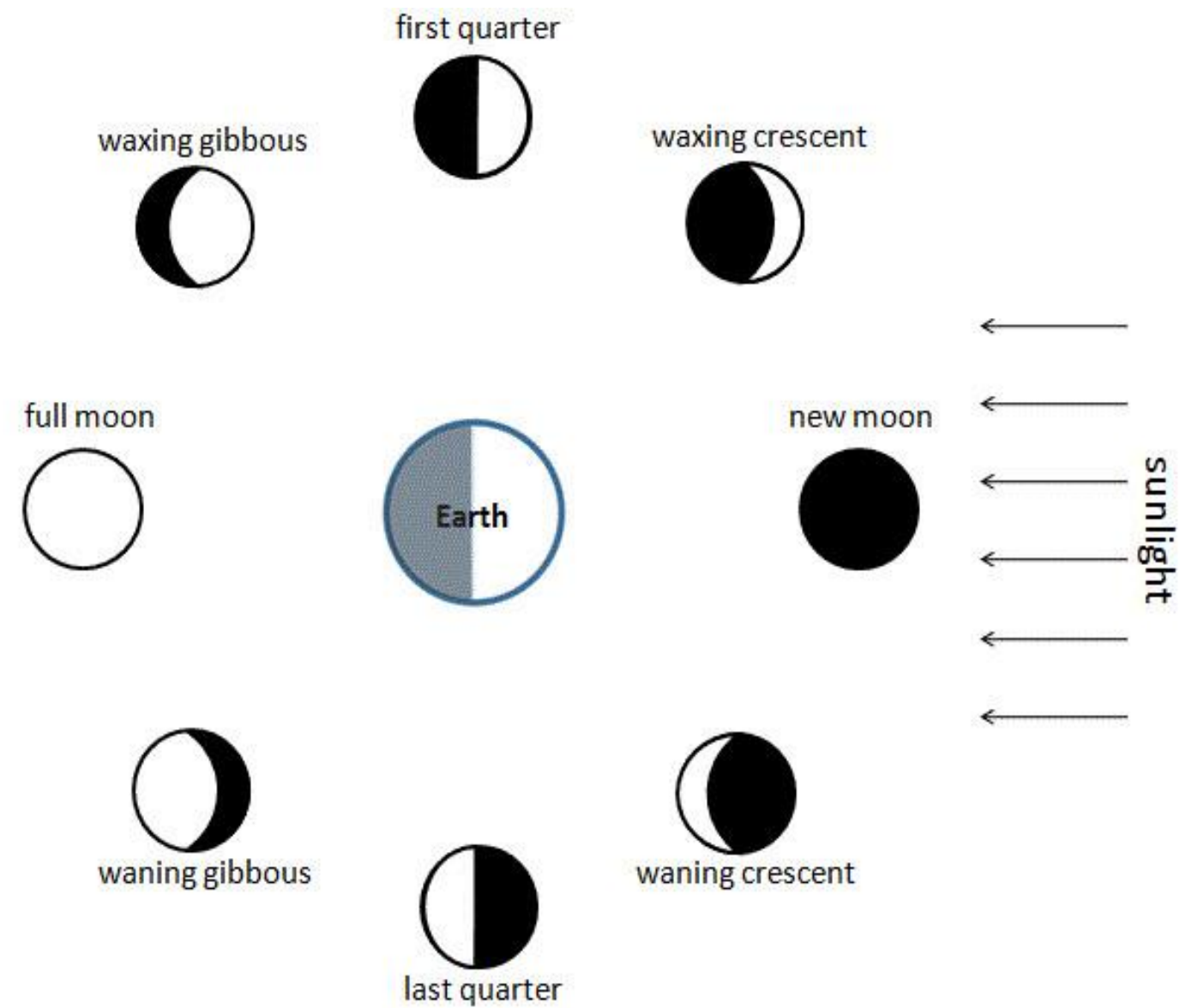

Fig. 1 Phases of Moon observed from northern hemisphere of Earth:

Earth is at the center and the Moon is shown orbiting. The Sun enlightens half of the Moon and Earth from the rightside. The phase of the Moon is shown next to the corresponding position of the Moon in its orbit around Earth. 


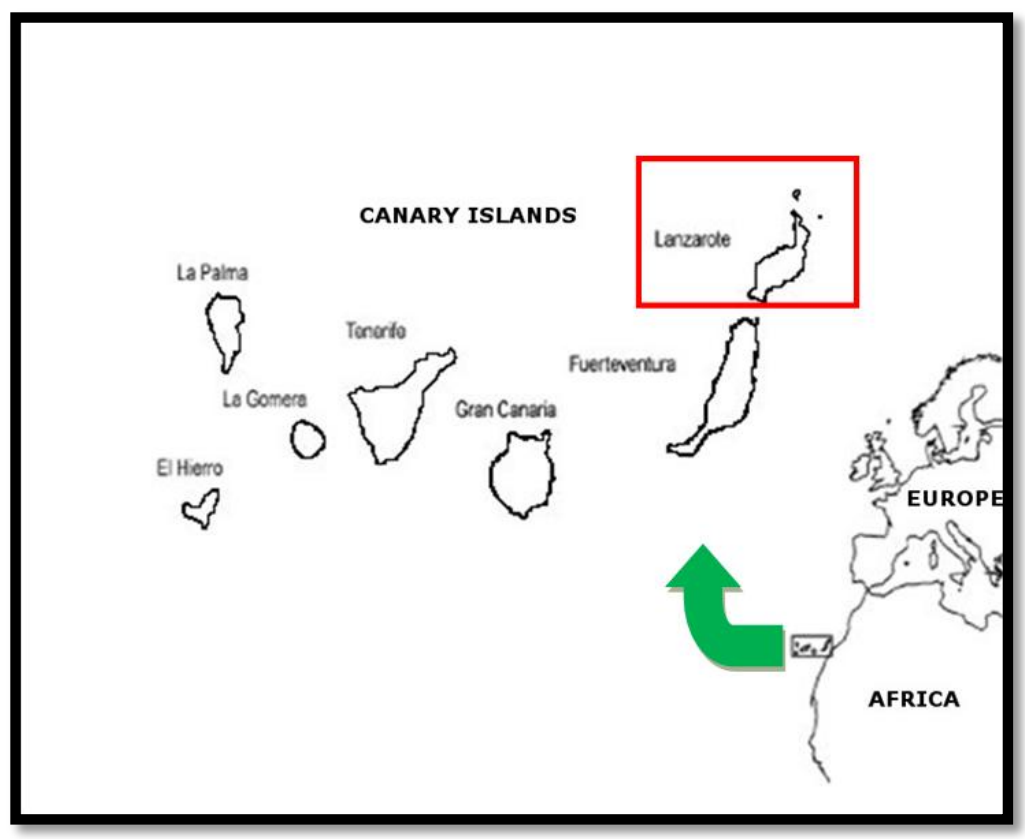

Fig. 2 Map of Canary Islands with their names and the Atlantic coast lines of Europe and North West Africa.

Lanzarote island is $125 \mathrm{~km}$ (78 miles) apart off African Coast. Present paper interest is on a prehistoric monument at Lanzarote (marked inside a red square).

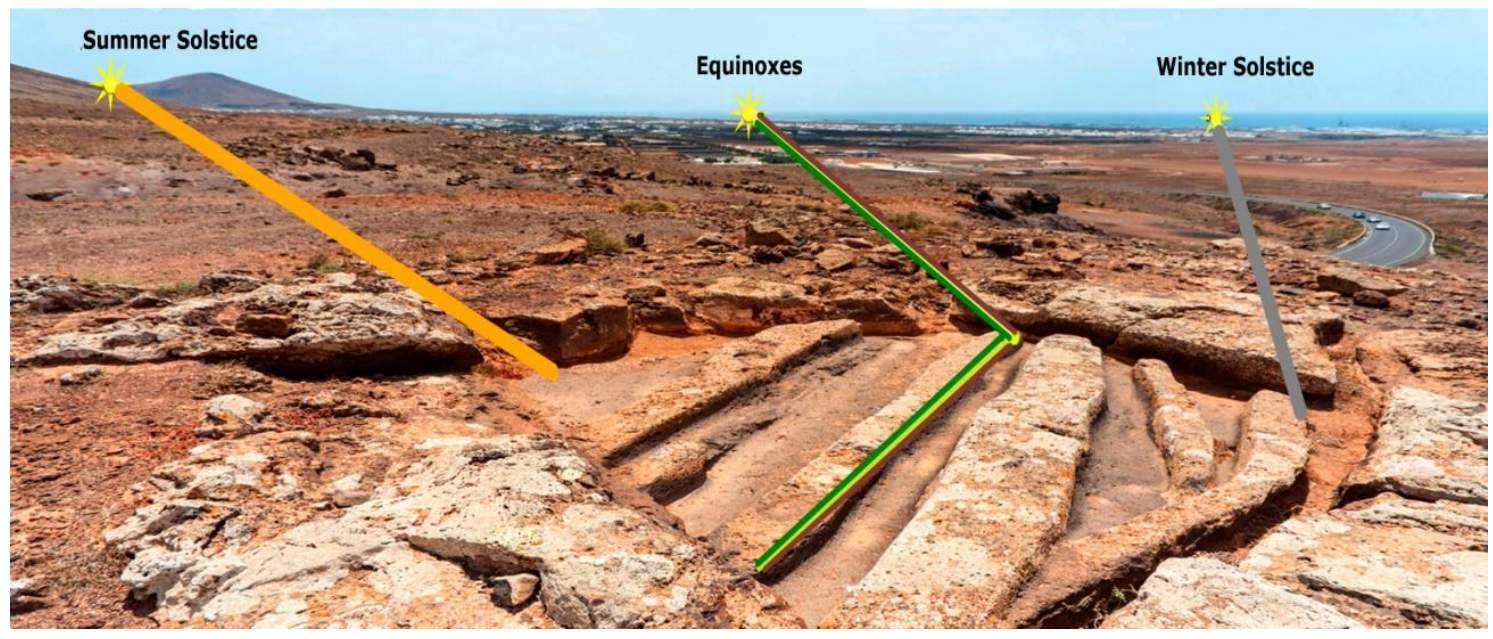

Fig. 3 Sunrise at Summer Solstices, Autumn/Spring Equinoxes and Winter Solstice from a "Quesera" observer (left to right). Photography from "Quesera" of Zonzamas (Lanzarote).

Left: Sun rises (2014 AD) between Maneje and Tahiche mountains at Summer Solstice (orange line). It is possible that if "Quesera" is ancient enough, an observer from this point might have seen Sun rising at Tahiche mountain slope or vertex in Antiquity because Ecliptic obliquity is diminishing about 0.47 arch seconds per year at present times. Middle: Sun rises at middle sea horizon, both at Autumn and Spring Equinoxes (green line).

Right: Sun rises at right sea horizon at Winter Solstice (grey line). Sunrises complete a yearly azimuth arch between $62^{\circ}$ and $117^{\circ}$ degrees going from June 21st to December 21st and back (Fig. 5, 6). 


\section{Material and Methods}

Study

One of the authors, Marcial Medina was born in Lanzarote and has lived close to "Quesera" of Zonzamas most of his life since age of seven years. He is a freelance archaeologist who has searched every Lanzarote's corner and has discovered many ancient rock engravings and other ceramic and archaeological tools. He has spent many days and nights close to "La Quesera" and finally he has become aware that it could be a calendar used by ancient "Majos" from Lanzarote (today included within the generic name of "Guanches" in English literature for all Canary Islands prehistoric inhabitants). He is a sailor and had knowledge of astronomic measurements. Thus, he took a simple compass (see below) and started to measuring sunrise azimuth and altitude (Magli, 2016) every day during a two years period (2014-2015) from the "Quesera" de Zorzamas elevation (162 meters, 629.92 feet above sea level) placed at $29.0005702^{\circ}$ North latitude and $1.5677934^{\circ}$ West longitude.

\section{Methods}

SPSMAP 60c color map Navigator was used for local coordinate assessment (Garmin International, Kansas, USA). Suunto Tandem/360PC/360R DG compass and clinometer (Turku, Finland) was used to record everyday azimuth and altitude during two years (2014 - 2015). Data were introduced in a computer program that calculated all other measurements from "Quesera" Zonzamas longitude / latitude location, (SunEarthTools.com, online program). Other instruments were used for reassessing measurements: above mentioned SPSMAP navigator and binoculars 7x50 Estancos Anti-Impactos with Plastimo Compass (Sea Binoculars, Plastino USA Inc, Wilmington, Delaware, USA).

\section{Results}

Full moonrise after summer solstice (observation on year 2014) was taking as starting of 2014 lunar year because of most reliable bibliography on ancient Canarians lunar calendar stated that it started after Summer solstice (Barrios García, 2004; Anonimo Cedeño, 1682; Marin de Cubas,1687) with some discrepancies that will be discussed, (see Table 1, Appendix 1). 
The following lunar months started with the next full moon phase and moon rise azimuth at that day is registered, according to observation and Sun Earth Tools.com, online program (Table 1, Appendix 1), which offers moonrise and moonset azimuth once local coordinates and specific daily sunrise azimuths are recorded.

Once first full moonrise day was taken as starting of old Canarians Lunar year and the first day of first month, Figures 4 and 5 were obtained. Figure 4 represents how "Quesera"/ Cheeseboard is able to register/represent both solar and lunar months. First full moonrise in year 2014 starts on July 12th a 29 solar days month; moonrise takes place and is represented the opposite side of "Quesera"/Cheeseboard side of the monument, (see also Appendix and Table 1). This first lunar month is represented in first prominent rock strip; 2nd lunar month has 30 solar days and is represented in the 2nd prominent rock strip and lunar months are consecutively represented in prominent rock strips (Fig. 4, Appendix 1); moonrise azimuths are depicted for each lunar month corresponding to the solar day that it starts. For example, sixth Moon month starts at $69^{\circ}$ azimuth (Fig. 4) and at December 6th 2014 (Table 1, Appendix 1) and it is represented in the 6th prominent rock strip which intermingles with solar months described by Medina and Arnaiz-Villena (2018) (Fig. 4).

In Figure 5 it is also represented a scheme of lunar months (hollow carved strips) and solar months (crested prominent strips). For example, 7th full moon starts at January 5th 2015, moonrise azimuth at that solar day is $71^{\circ}$ from "Quesera"/ Cheeseboard; it is represented in the 1st hollow strip (Fig. 5), where the 1st solar month was represented (Fig. 4). See also Table 1 and Appendix 1.

Moonsets are given by Sun Earth Tools.com online software program; they cannot usually be observed because of day light. Figure 5 also shows starting of following lunar months that are represented in "Quesera"/Cheeseboard carved strips (lunar months 8th, 9th, 10th and 12th). See also Table 1 and Appendix 1.

Therefore each "Quesera"/Cheeseboards crest and hollow/carved strip is used for both registering/representing solar and lunar months (Figs 4 and 5). 


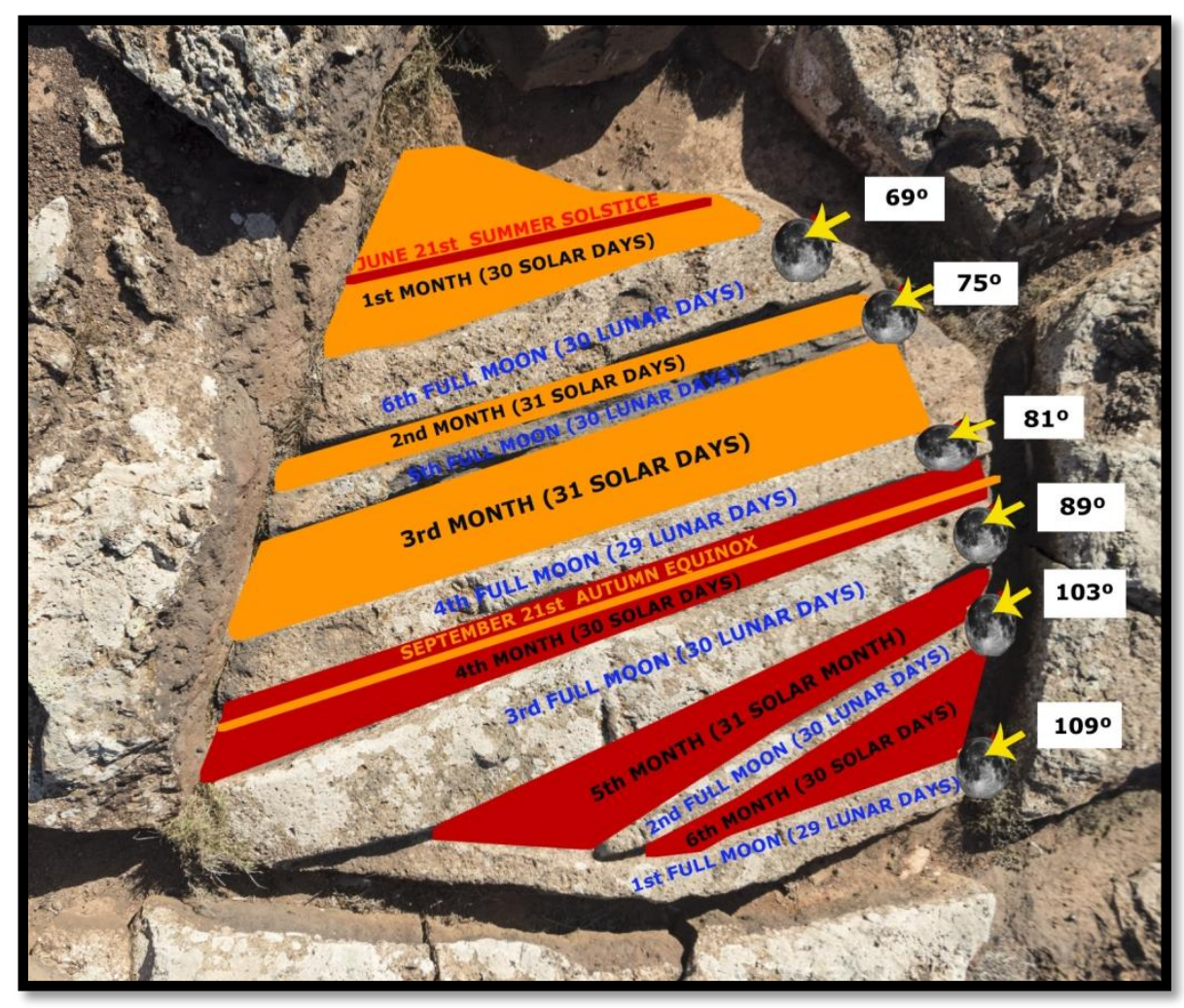

Fig. 4 Lunisolar "Quesera"/Cheeseboard Prehistoric Canarian Calendar (First half year time).

Sun Calendar: was studied in a previous paper (Medina and Arnaiz-Villena, 2008). First half of solar year (six solar months) is shown starting in the 21st Summer Solstice. Solar months are registered / represented in hollow carved strips; solar months follow from top to bottom up to 6th solar month.

Sunrises and Sunsets azimuths for solstices and equinoxes are given in Fig. 6 of Ref. Medina and ArnaizVillena, 2018, a previous paper analyzing only Sun calendar. Note that Sunsets azimuths for Equinoxes are at $271^{\circ}$ in Figure 6 of previous paper and there is mistake there, as it is stated "Azimuth Sunrise" instead of azimuth sunset.

Lunar Calendar: starts with its first prominent botton rock strip. The following lunar months (2nd-6th) are recorded in the following prominent rock strips upwards in figure. Starting lunar month azimuths are depicted in white squares. See Table 1 and Appendix 1 (Anónimo Cedeño, 1682; Marin de Cubas, 1687; Barrios García, 2004). 


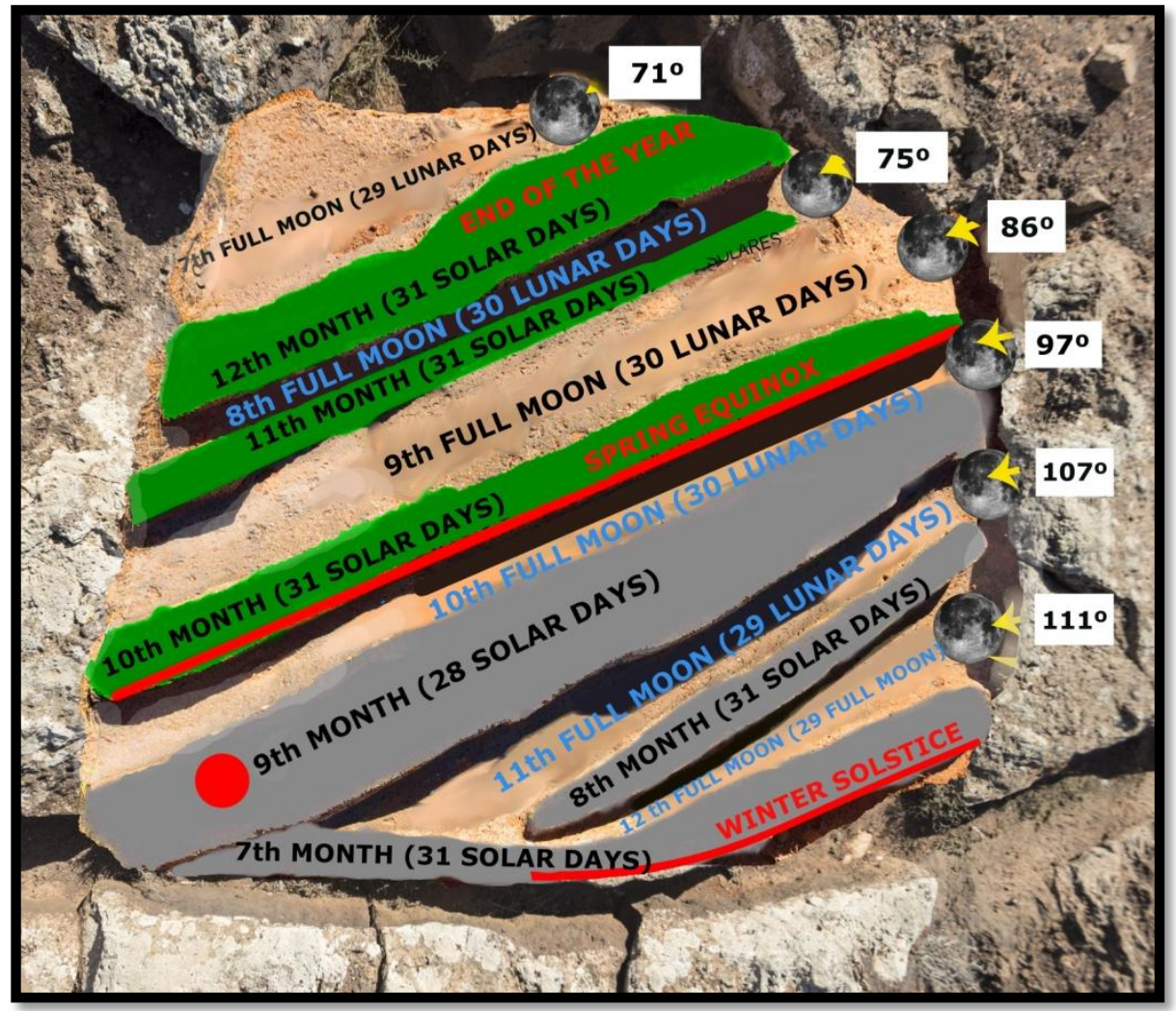

Fig.5 Lunisolar "Quesera"/Cheeseboard Prehistoric Canarian Calendar (Second half year time).

Sun Calendar: was studied in a previous paper (Medina and Arnaiz-Villena, 2008). Second half of year is represented in this figure; the solar month was shown in the first bottom prominent strip and following sun months were shown in the following upwards prominent rock strips. Sunrises and Sunsets azimuths for solstices and equinoxes are given in Fig. 6 of Ref. Medina and Arnaiz-Villena, 2018, a previous paper analyzing only Sun calendar. Note that Sunsets azimuths for Equinoxes are at $271^{\circ}$ in Fig. 6 of previous paper and there is mistake there, as they are stated "Azimuth Sunrise" instead of azimuth sunset.

Lunar Calendar: The lunar month is represented in first top hollow carved strip at $71^{\circ}$ moonrise azimuth January 7th 2015; following lunar months are represented in the following bottom wards hollow/carved strips. Starting lunar month azimuths are depicted in white squares. See Table 1 and Appendix 1 for consulting first lunar months day and sunrise azimuth and moonset (Anónimo Cedeño, 1682; Marín de Cubas, 1687; Barrios García, 2004). 
Table 1. Moon Month Starting-Full Moonrise (2014-2015)

See also Appendix 1 at the end of References section. First month moonrise could be observed at $109^{\circ}$ from Zonzamas-Cheeseboard. Their data was taken according to references (Anonimo Cedeño, 1682;

Marin de Cubas, 1687; Barrios-García, 2004). See also Table 1, Figs 4, 5 and Appendix 1.

\begin{tabular}{|c|c|c|}
\hline LUNAR MONTH & CIVIL SOLAR CALENDAR & FULL MOONRISE AZIMUTH \\
\hline 1st & July 12th2014 & $109^{\circ}$ \\
\hline 2nd & August 10th2014 & $103^{\circ}$ \\
\hline 3rd & September 9th 2014 & $89^{\circ}$ \\
\hline 4th & October 8th 2014 & $7^{\circ}$ \\
\hline 5th & November 6th 2014 & $69^{\circ}$ \\
\hline 6th & December 6th 2014 & $71^{\circ}$ \\
\hline 7th & January 5th 2015 & $75^{\circ}$ \\
\hline 8th & February 3rd 2015 & $86^{\circ}$ \\
\hline 9th & March 5th 2015 & $97^{\circ}$ \\
\hline 10th & April 4th 2015 & $107^{\circ}$ \\
\hline 11th & May 4th 2015 & $11^{\circ}$ \\
\hline 12th & June 2nd 2015 & \\
\hline & & \\
\hline
\end{tabular}

\section{Discussion}

Context of Canary Islands rock art and other prehistoric artifacts: History, genetics, rock scripts. Cheeseboard/"Quesera" dating.

Context and dates for most Canarian archaeological patrimony was yet lacking in 1996 according to Beltran (1996). However, he related prehistoric Canarian Art Rock with Atlantic Megalithic Age, Bronze Age, Mediterranean and North African ancient cultures. Later, an attempt to a rational dating was accomplished because a lack of absolute dating (i.e.: C14) in Canarian archaeological patrimony still existed (Atoche Peña \& Ramirez Rodriguez, 2009); these authors recognized that objective time measurement was still necessary to place in context many Canarian prehistoric archaeological items. In addition, they have more recently obtained C14 absolute dating for 43 different samples coming from 4 archaeological sites from all over Lanzarote 
Island (Atoche Peña \& Ramirez Rodriguez, 2016). An age estimation of $2 \mathrm{nd} / 1 \mathrm{st}$ millennium BC was found for the items; some of them were dated as old as 1300 years BC from El Bebedero site (Lanzarote Island).

Complex issues like the study of Past should be addressed with help of several approaches or scientific disciplines, because univocal scientific views for complex matters have usually failed due to academic dogma established in each field; a more complete and open approach to topics, like History or Language, should be used. In a previous paper (Medina \& Arnaiz-Villena, 2018) and in the present one, we have described a lunisolar calendar represented by a monument (Cheeseboard/"Quesera") in one of the Canary Islands: Lanzarote. It is useful to take into account different scientific fields for approaching to the prehistoric age in which Cheeseboard/"Quesera" was built.

\section{Language}

Ancient Iberian writing graffiti (also named "Latin" inscriptions) are found all over Fuerteventura and Lanzarote islands rocks. This Iberian-"Guanche" or "Ibero-Canarian" inscriptions are more ancient than Lybic (Berber) inscriptions which are usually engraved over (over the top of) ancient Iberian-"Guanche" inscriptions on the rocks where the two writing types are found together. These two kinds of inscriptions are very frequently close to each other in the same rock place. (Arnaiz-Villena et al, 2001, 2015; Medina and Arnaiz-Villena, 2018)

Iberian writing in Iberia, France and Mediterranean Islands is at least found as old as the beginning at 1st millennium BC. However, this dating is not measured by absolute means and may be older. Origin of Iberian-"Guanche" or Iberian-Canarian scripts (named also as "Latin” scripts by Pichler, 2010), and even Punic by others: see review by (Atoche and Ramirez Rodriguez, 2009). It is possible that this Iberian"Guanche" writing may thus be of either Iberian or African origin, as it is found that frequently in Lanzarote, Fuerteventura and even in El Hierro Canary Islands (Arnaiz Villena et al., 2015; Ulbricht, 1990).

\section{Genetics}

Our group has been studying North Africa genetic relationship with Iberia (ArnaizVillena, 1999, 2002, 2015, 2017). Recently a meta-analysis always using 56 Mediterranean and African population and 20,566 chromosomes have found that groups of almost all North Africa, above Sahara and also Yemen and Saudi Arabia are 
genetically related with Iberia according to HLA genes (Hajjej, 2018). Also, it is proposed that classic Greek and Roman authors referred to Celts who had not a clear distinction from Iberians; they might often referred to the same population (ArnaizVillena et al, 2015; Arnaiz-Villena et al, 2017). Canarians have been genetically related with both Atlantic and North African (Berbers)-Mediterraneans (Arnaiz-Villena, 2015) and also on cultural archaeological traits bases (Beltran, 1990). Thus, it is useless to genetically try to distinguish North Africans, Iberians and Canarians: all of them share a similar genetic pool.

In conclusion, archaeological absolute C14 data, genetic and linguistics show that Lanzarote prehistoric artifacts may have been constructed by Canarians long time before Phoenicians and Romans reached Canary Islands, and they also are in a separate historical and cultural context.

\section{The Moon in the Lunisolar Calendar}

Moon or lunar calendars were soon used since Paleolithic times, including a Basque calendar (Naberan, 2006) and easy to observe (Magli, 2016). However, when agriculture was important for Humans in Neolithic times it was necessary to precisely record yearly seasons measurement in order to correctly accomplish sowing and harvesting. Other type of calendars were also used for other events, for example Egyptians had star calendars for marking and predicting Nile flooding (Magli, 2016; Britannic Encyclopedia Online, 2008)

However, lunar calendars are easy to observe but they are more unstable and difficult to be kept a constant type of time record. It is necessary to maintain constant and time record relating Moon year with a Sun year; the latter is the time that Earth rotates around Sun taking into account seasons, wherever they exist in Earth and it is necessary to be able to record for agriculture managing in different seasons.

In order to construct a solid and stable lunisolar calendar, it is necessary to add an additional lunar month each 2-3 years in the lunar calendar. A synodic lunar calendar has one year with 12 synodic months and lasts 354.36 days composed of alternate 29 and 30 days months. A lunisolar calendar, like the one studied in this paper (Cheeseboard/"Quesera") is constructed for maintaining synchrony of Moon phases with Solar/tropical year. It has 12 synodic months and one more synodic month is added each 2-3 years, for adjusting to the Solar year starting (note that solar year has more days: 365.24 (Magli, 2016; Britannic Encyclopedia Online, 2008). 
Another easy lunar calendar approximation to a solar calendar is as follows; 37 sidereal months add up to 1,093 days which correspond to 3 solar years with 364.25 days each. Other approximation was described by Greek Meton (who lived at 432 year BC): 235 Lunar months of 29.5 days add up to 19 solar years of 365.25 days each. (Magli, 2016; Britannic Encyclopedia Online, 2008) Other cultures have a strict lunar calendar (Muslims) without correction (Magli, 2016). Our official western World calendar is a solar one with corrections (leap year, adding one extra day in February) each 4 years but with some "lunar corrections" for celebrations, i.e.: first Friday close to full Moon after Spring Equinox is used to celebrate death of Christ. Other cultures, like Old Canarians could have used Moon calendars also for festivities in addition to follow a strict solar calendar for sowing and harvesting. This lunisolar calendar is represented by Cheeseboard/"Quesera" Lanzarote monument (see Barrios García, 2004)

\section{Canarian calendars}

Several authors have written different views about prehistoric Canarian calendars (Barrios García, 2004). Anonimo Cedeño (1934 [1682-1687]) states that one year had 12 Moon months and days were counted as a solar day (Anónimo Cedeño, 1682). Marin de Cubas, in Marin de Cubas1986 [1694], states that ancient Canarians constructed the year with Moon months. Each Moon month had 29 solar days: starting of year was summer solstice (around June 21st) and starting Moon year apparently started at first full Moon after June 21st (see Marín de Cubas, 1687). This is the same type of calendar records that we have followed in the present work. Both authors confirm that days were solar, week was composed of 7 days and big harvest and other celebration started by the first (Full) Moon after Summer Solstice. Some other suggestions stated that Sirius star rising was another mark for the year in prehistory of Canary Islands (Barrios Garcia, 2004). Observations on Lunar calendar related in present paper are shown in the Results section and in Appendix 1.

We do not know if ancient Canarians made corrections for adjusting lunar to solar calendar year. It is thought that they did: i.e.: by adding one full lunar month each 2-3 solar year or following a metonic or other type of correction. See ref Barrios Garcia, (2004) for a detailed study of possible corrections, including taking into account that Moon orbit around Earth is separated $5^{\circ} 145^{\prime}$ from ecliptic plane. 
Finally, it is most interesting that Barrios García (2004) describes a calendar based on Summer solstice Sun shadows on an enigmatic drawing that is placed at "Cuatro Puertas" Mountain, Telde, Gran Canaria Island. This archaeological site is placed close to the mountain top and it is considered a sacred place. This method of marking Summer solstice (a shadow) used by prehistoric Canarians is concordant with the Basque/Iberian translation of "Achano" or "Atxano" (Anónimo Cedeño, 1682) "Atx"=stick, axis=hill; "ano"=shadow. This is also concordant for all Canary Islands with the many Canarian place names and ancient people names ("Guanches" for all islands or "Majos" for Lanzarote/Fuerteventura) that are found throughout Cananry Islands and Lanzarote/Fuerteventura Iberian rock scripts (Arnaiz-Villena and Alonso García, 2001, Arnaiz-Villena et al., 2015). We do not know yet whether Tahiche mountain shadow or strategic sticks put into Cheeseboard/"Quesera" itself could have also been used by ancient Canarians for time measurement through measuring stick shadows as suggested by "Achano" proposed translation.

\section{Cheeseboard/"Quesera" Age of Building: Megalithic Canarian "Bronze"/Pyramid Epoch?"Cart-ruts"}

This monument proposed and analyzed by us like a lunisolar calendar has no Punic or Roman characters. It must have been built up by prehistoric Canarians, before both cultures reached Atlantic/African western Mediterranean area. Several other Cheeseboard/"Queseras" have been also found in Lanzarote Island (Medina and ArnaizVillena, 2018).

Archaeological absolute dating has also been calculated for found artifacts previous to Punic and Romans times (Atoche Peña and Ramirez Rodriguez, 2016). The stone work for this monument must culturally be included in a megalithic context whatever dates this epoch had in Lanzarote. Iberian, other Macaronesia Islands: Azores and Madeira British, Moroccan and Mediterranean megaliths are dated about 5-4,000 years BC, 1-2,000 years before that Giza Egiptian pyramids were built 3,000 years BC (Braem, 2010; Fanjul Pedraza, 2003; Ribero et al., 2017; Arnaiz-Villena et al., 2015). Pyramids have also been found in Canary Islands and Azores. Other prehistoric artifacts and constructions have been found also in Madeira, showing that Macaronesia Islands 
where inhabited in prehistoric times, including possibly in Megalithic Epoch (Ribeiro et al., 2015, 2017; Rodrigues et al., 2015)

A particular mention to the unexplained phenomenon of "cart-ruts" must be made. They are present in Malta, Azores (Trump, 2002; Ribeiro et al., 2015, 2017; Rodrigues et al., 2015; Rodrigues communication), Iberia, Turkey and other parts of the World. "Cart-ruts" have been assigned to Megalithic culture/Pyramid culture in Malta with and age between 5,000-3,000 years BC which may be different depending on the analyzed place (Trump, 2002), they are carved rock strips and crests that cover many places of Malta archipelago. They are mostly almost parallel, but not completely. Width and length are variable. In many aspects, they resemble Cheeseboard/"Quesera" strips. This type of thin "cart-ruts" crests may be seen in Lanzarote Island at Montaña Blanca and several other places (San Bartolome, personal observation). We put forward that they may be related to time measurement in Prehistory together with a stick (or other axes, like plants or hills) shadows to make rock sundials. Also, they may be mixed lunisolar and/or star calendars or they might have been used as compasses to find out or establishing directions among another proposed functions (Trump, 2002; Magli, 2016).

In addition, an absolute C14 dating of Lanzarote archaeology shows that artifacts (and people) existed in the island in prehistoric times, before Punic or Roman influence may have arrived (Atoche Peña and Ramon Rodriguez, 2016). Genetics shows us that an important emigration occurred from Sahara to Iberia and other places about 10,000 year ago when desertification began. Thus, people may have also reached Canary Islands by then (Arnaiz-Villena et al., 1999, 2002, 2015, 2017; Hajjej et al., 2018).

Lastly, Lanzarote and Fuerteventura are covered by old Iberian writing rock scripts, which are more ancient than old Lybian scripts that are often written on the top of Iberian ones (Arnaiz-Villena and Alonso-Garcia, 2002; personal observation of Lanzarote and Fuerteventura script sites). This finding needs yet to be explained.

In conclusion, cultural, genetic, archaeological non-absolute data and archaeological C14 absolute data support the existence of a prehistoric Megalithic/Pyramid culture people who inhabited Canary Islands and built up Cheeseboard/"Quesera" calendar, named in English "Guanches" for all Canary Islands and also "Majos" for Lanzarote and Fuerteventura Islands. 


\section{Acknowledgments}

We thank University Complutense from Madrid (Spain) for its support and the following colleges who have been important for carrying out present work and conceiving and writing present paper: Julián Rodríguez Rodríguez, Antonio Jesús Montelongo Franquiz, María Antonia Perera Betancor, Máximino Álvarez Pérez, José Manuel Espinel Cejas, Ramón Alfonso Hernández and Orlando Batista Aparicio. Also, we thank Valentín Ruiz-del-Valle by continuously pushing since several years ago about publishing abroad this "Quesera" prehistoric monument. Marianne Van der Sluys and Jesús Gonzalez Artabe were (and are) also important for spreading light in Lanzarote archaeology and their help is indebted. Finally it has been particularly important Adrián López Nares, who has put together in paper all pieces of this present research.

Conflicts of Interest: The authors declare no conflict of interest.

\section{References}

Anónimo Cedeño. (Antonio Cedeño?). 1682. Naturalezza y Costumbres particulares según otros autores [Copied by Marin de Cubas TA]. Manuscript film-Millares Carlos): Museo Canario, Las Palmas, Gran Canaria, Islas Canarias (Spain).

Arnaiz-Villena A., MartÍnez-Laso J., Alonso-García J. 1999. Iberia: Population Genetics, Anthropology, and Linguistics. Human Biology 71: 725-743.

Arnaiz-Villena A. \& Alonso García J. 2001. Egipcios, Bereberes, Guanches y Vascos. Ed. Visión Libros. (3rd Edition 2011) ACCI. Madrid (Spain).

Arnaiz-Villena A., Gomez-Casado E., Martinez Laso J. 2002. Population genetic relationships between Mediterranean populations determined by HLA allele distribution and a historic perspective. Tissue Antigens 60: 111-121.

Arnaiz-Villena A., Muñiz E., Campos C., Gómez-Casado E., Tomasi S., MartínezQuiles N., Martín-Villa M., Palacio-Gruber J. 2015. Origin of Ancient Canary Islanders (Guanches): presence of Atlantic/Iberian HLA and Y chromosome genes and Ancient Iberian language. Int. J. Mod. Anthrop 8: 67-93.

Arnaiz-Villena A., Carballo A., Juarez I., Muñiz E., Campos C., Tejedor B., MartínVilla M., Palacio-Gruber J. 2017. HLA Genes in Atlantic Celtic populations: Are Celts Iberians? Int. J. Mod. Anthrop 10: 50 - 72. 
Atoche Peña P. \& Ramirez Rodriguez M.A. 2009. Manifestaciones rupestres protohistoricas de Lanzarote pp 187-209, in "rock carvings of the European and African Atlantic Façade". Ed. Blablu Behrkay et al. 2043, Archaeopress, Oxford (UK).

Atoche Peña P. \& Ramirez Rodriguez MA. 2016. C14 References and Cultural Sequence in the Protohistory of Lanzarote (Canary Islands), Iber-Crono.Actas del Congreso de Cronometrias para la Peninsula Iberica, pp 272-285. Barcelona (Spain). Available at Research Gate.

Beltrán, A. 1996. Introducción. In "Manifestaciones rupestres de las Islas Canarias", pp: 9-24. Santa Cruz de Tenerife. Edited by: Dirección General de Patrimonio Histórico.

Braem H. 2010. Tras las huellas de los aborigenes. Ed. Zech Santa Ursula. Tenerife, Canary Islands (Spain).

Barrios García J. 2004. Sistemas de numeración y calendarios de las poblaciones bereberes de Gran Canaria y Tenerife en los siglos XIV-XV. Thesis doctoral. Universidad de La Laguna, Tenerife, Islas Canarias (Spain).

http://www.etnomatematica.org/publica/trabajos_doctorado/tenerife.pdf

Britannic Encyclopedia online. 2008. "Calendar" article.

Fanjul Peraza A. 2003. Megalitos en Marruecos. http://academia.edu

Hajjej A., Almawi WY., Arnaiz-Villena A., Hattab L., Hmida S. 2018. The genetic heterogeneity of Arab populations as inferred from HLA genes. PLoS ONE 13(3): e0192269. https:// doi.org/10.1371/journal.pone.0192269

Magli G. 2016. Archaeoastronomy: introduction to the science of star and stones. Ed.Springuer Iternational Publishing Switzerland.

Marín de Cubas T.A. 1687. Historia de las Siete de la Gran Canaria Ed. Príncipe. Transcripción de F.Osorio Acevedo. Canarias Clasica.1993. La Laguna, Tenerife, Islas Canarias (Spain).

Medina M \& Arnaiz-Villena A. 2018. A lunisolar prehistoric calendar in Lanzarote Island:"La Quesera"(Cheesboard) from Zonzamas. Int. J. Med. Anthrop. 21:147-161

Naberan, 2006. El antiguo calendario lunar vasco. Ed. Basandere Argitalextea. San Sebastian (Spain).

Pichler W., 2010. Las inscripciones rupestres de Fuerteventura. Ed.Calildo de Fuertevfentura, Puerta de Rosario, Fuerteventura, Canary Islands (spain).

Ribeiro N., Joaquinito A., Rodrigues Af., Azevedo M.T. 2015. Achaeology and rock art of Macaronesia: New contributions. IV Encontro de Doutorandos e Post-Douorandos Macao. 
Ribeiro N., Joaquinito A., Rodrigues AF., Azevedo MT. 2017. Arqueologia e Arte Rupestre na Macronesia, novos contributos. Techne. 3: 113-124.

Rodrigues AF., Martins NO., Ribeiro N., Joaquinito A. 2015. Early Atlantic Navigation: Pre-Portuguese Presence in the Azores Islands. Archaeological Discovery. 3: 104-113.

Trump D. 2002. Malta, prehistory and Temples.Ed. Midsea Books Ltd., Malta.

Ulbricht, M.J. Die Feldsildforschung auf Lanzarote. Almogaren XXI/2/1990, Hallein (1990), Salzburg, Austria

\section{Appendix 1.}

Daily observations of sunrise azimuths during year 2014 / 2015

Place: "Quesera"/Cheeseboard of Zonzamas. Lanzarote Is. Canary Islands. Starting and finishing of both solar and lunar months are stated together with moonrise azimuths, Moon phases, moonrise, sunrise and sunset hours. See also Figs. 4 and 5. 


\section{Moonrise, Moonset, Sunrise and Sunset}

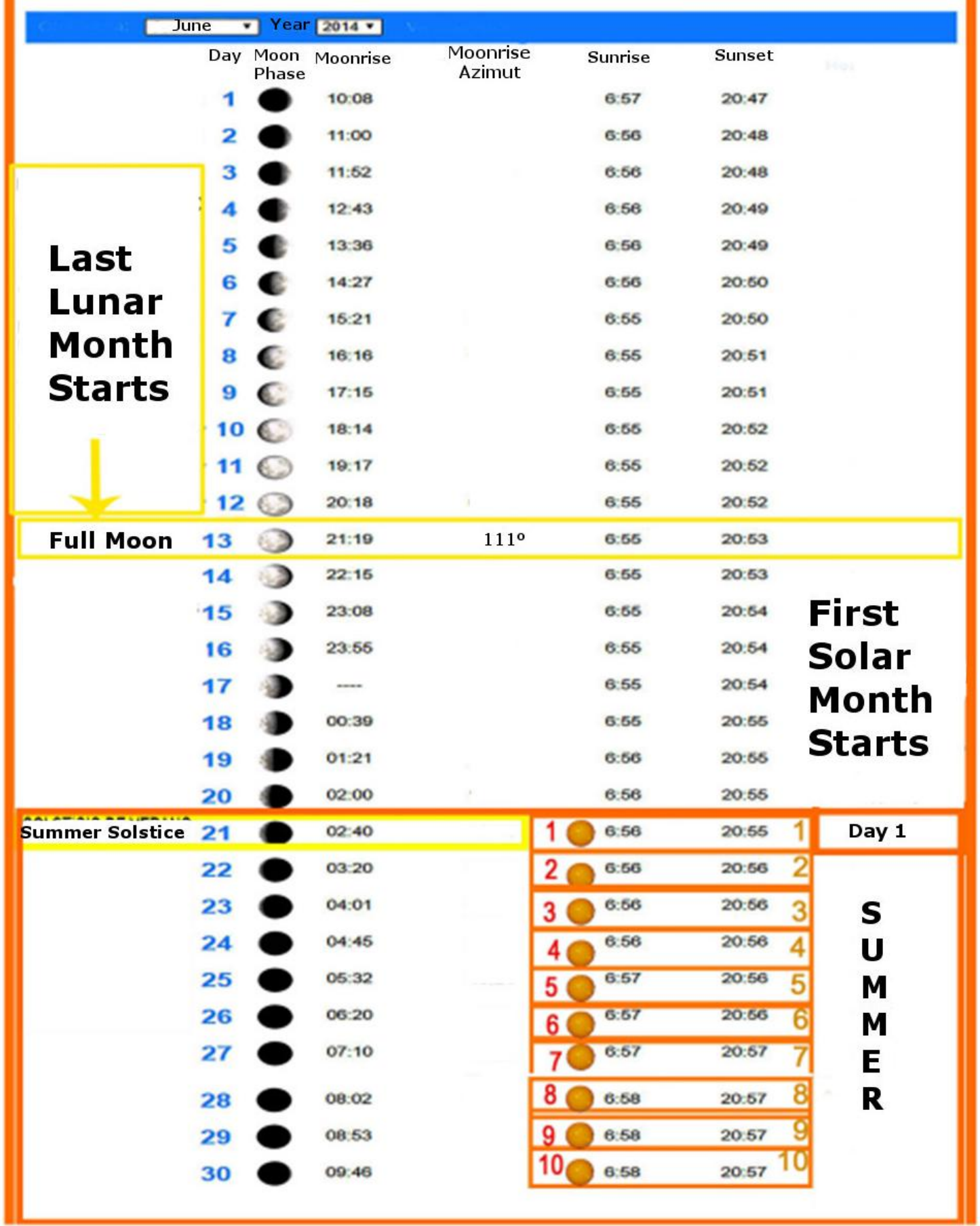


2

July * Year 2014 v

Day Lunar Moonrisı Moonrise

Phase Moonrisı Azimut

$1 \bigcirc 10: 37$

$2 \bigcirc 11: 29$

$3 \bigcirc 12: 20$

$4013: 12$

$5 \quad 14: 05$

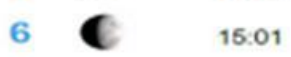

$7 \quad 16: 68$

8 C 16:58

$9 \quad 17: 59$

$10 \div \quad 19: 00$

$11 \quad 19.59$

Full Moon $12 \circlearrowleft 20.55$

$\begin{array}{llll}\text { First } & 13 & 0\end{array}$

Lunar $14{ }^{14}$

Month $15 \quad$ 23:18

Starts 16 23:59

$\begin{array}{rrc}17 & \mathbf{D} & \cdots-\cdot \\ 18 & \mathbf{D} & 00.40\end{array}$

$1901: 21$

20 02:02

$2102: 45$

$22 \bigcirc 03: 30$

$23 \bigcirc 04: 17$

$24 \bigcirc 05: 07$

$25 \bigcirc 05.57$

$26 \bigcirc 06: 49$

$27 \bigcirc 07: 41$

$28 \bigcirc 08.32$

$29 \bigcirc 09.24$

$30 \bigcirc 10: 15$

31

11:06 $109^{\circ}$

\begin{tabular}{|c|c|}
\hline Sunrise & Sunset \\
\hline $116: 58$ & $20: 57 \quad 11$ \\
\hline $126: 59$ & $20-57 \quad 12$ \\
\hline $136: 59$ & $20: 57 \quad 13$ \\
\hline $147: 00$ & $20.57 \quad 14$ \\
\hline $15^{7: 00}$ & 20.57 \\
\hline $16^{7: 00}$ & 20:57 16 \\
\hline $17^{7: 01}$ & $\begin{array}{ll}20: 67 & 17\end{array}$ \\
\hline $18^{7: 01}$ & $\begin{array}{ll}20: 67 & 18\end{array}$ \\
\hline $19^{702}$ & $\begin{array}{ll}20: 57 & 19\end{array}$ \\
\hline $207: 02$ & $20: 57 \quad 20$ \\
\hline $217: 03$ & $20: 56 \quad 21$ \\
\hline $227: 03$ & $20.56 \quad 22$ \\
\hline
\end{tabular}

\begin{tabular}{|lll|}
\hline $23^{7: 04} \bigcirc$ & $20: 56$ & 23 \\
\hline $247: 04 \bigcirc$ & $20: 56$ & 24 \\
\hline
\end{tabular}

$257: 05 \bigcirc 25$

26 7:05 20:55 26 First

$27 \begin{array}{lll}7.06 \bigcirc & 20.55 & 27 \\ \text { Solar }\end{array}$

$\begin{array}{lll}287.06 \bigcirc 20.55 \quad 28 & \text { Month }\end{array}$ $29_{7: 07} \bigcirc 20.54 \quad 29$ Ends

30 7:07 20:54 30 30 days

\begin{tabular}{lll}
$317: 08 \cup 20: 53$ & 1 & $\begin{array}{l}\text { Second Solar } \\
\text { Month Starts }\end{array}$ \\
\hline
\end{tabular}

$32^{7: 08} \quad 20: 53 \quad 2$

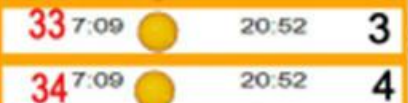

$35^{7: 10} \bigcirc 20.52 \quad 5$

$367: 10 \bigcirc 20: 51 \quad 6$

$37^{7: 11} \quad 20: 50 \quad 7$

$38^{7: 12 \bigcirc \quad 20: 50 \quad 8}$

$397: 12 \bigcirc \quad 20: 49 \quad 9$

\begin{tabular}{|lll}
\hline $407: 13 \bigcirc$ & $20: 49$ & 10 \\
\hline $417: 13 \bigcirc$ & $20: 48$ & 11
\end{tabular}




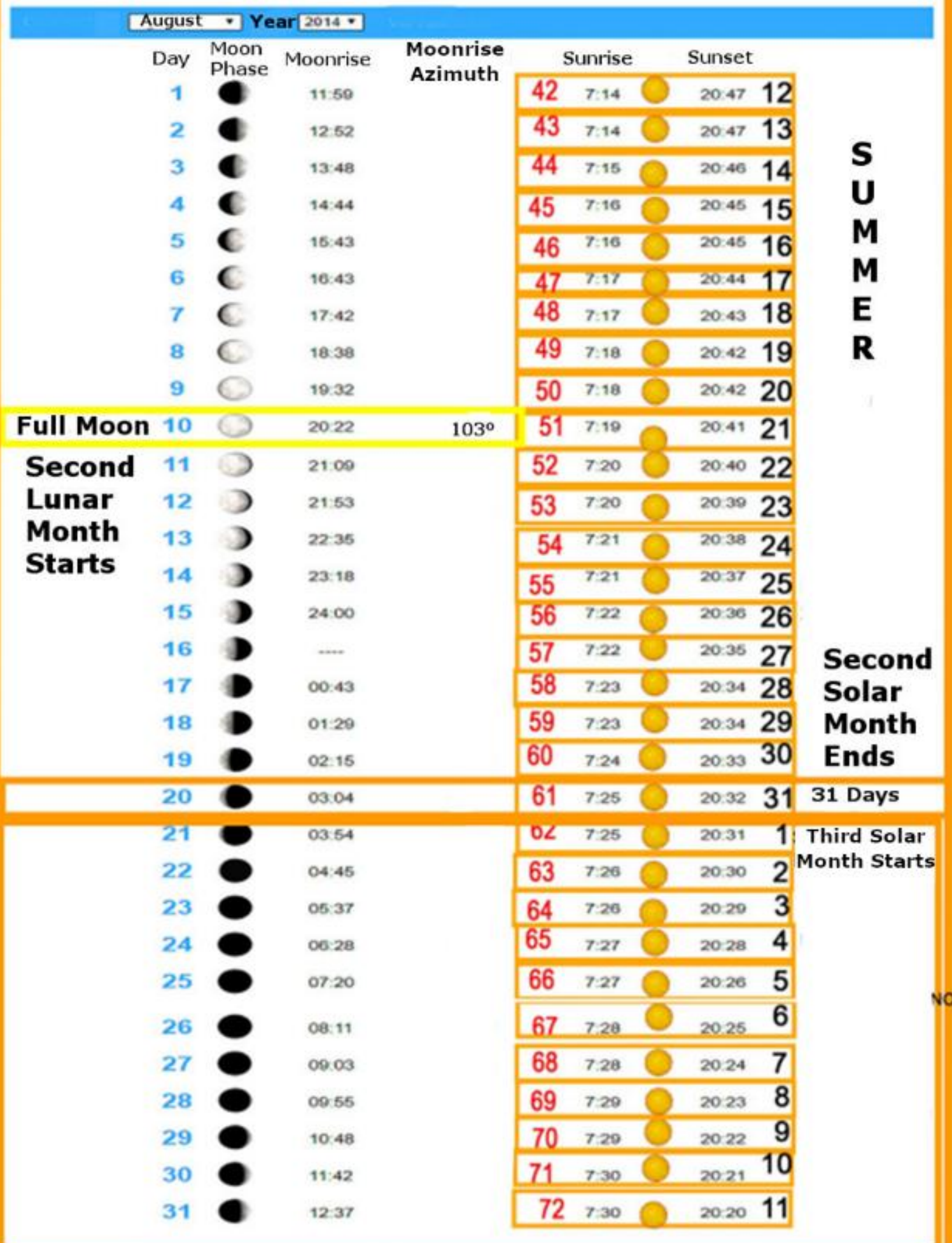




\begin{tabular}{|c|c|c|c|c|c|c|c|c|}
\hline \multicolumn{9}{|c|}{ September 0 Year $2014^{\circ}$} \\
\hline & Day & Moon & Moonrise & Moonrise & & unrise & Sunset & \multirow{20}{*}{$\begin{array}{l}\text { S } \\
\mathbf{U} \\
\mathbf{M} \\
\mathbf{M} \\
\mathbf{E} \\
\mathbf{R} \\
\\
\\
\\
\\
\\
\text { Third } \\
\text { Solar } \\
\text { Month } \\
\text { Ends }\end{array}$} \\
\hline & 1 & & 13.34 & & 73 & $7: 310$ & $20: 1912$ & \\
\hline & 2 & & 14.31 & & 74 & $7: 310$ & $20: 1813$ & \\
\hline & 3 & 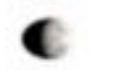 & $15: 20$ & & 75 & ${ }^{732} \mathrm{O}$ & $20: 1714$ & \\
\hline & 4 & C & 1624 & & 76 & $7: 32 \Omega$ & $20: 1515$ & \\
\hline & 5 & C & $17: 18$ & & 77 & ${ }^{733} \mathrm{O}$ & $20: 1416$ & \\
\hline & 6 & C & 18.08 & & 78 & $7: 34$ & 20.1317 & \\
\hline & 7 & C & 18.68 & & 79 & $7: 340$ & $20: 1218$ & \\
\hline & R & $\Omega$ & 19.42 & & 80 & $735 \Omega$ & $20: 1119$ & \\
\hline Full Moon & 9 & 0 & 20.26 & $89^{\circ}$ & & 7.350 & $20: 10^{20}$ & \\
\hline \multirow{21}{*}{$\begin{array}{l}\text { Third } \\
\text { Lunar } \\
\text { Month } \\
\text { Starts }\end{array}$} & 10 & 3 & $21: 00$ & & 82 & 7.360 & $20.08^{21}$ & \\
\hline & 11 & & 21.53 & & 83 & 7360 & $20-0722$ & \\
\hline & 12 & & 22.37 & & 84 & 7370 & 20.0623 & \\
\hline & 13 & & 23.23 & & 85 & 7.378 & $20-0524$ & \\
\hline & 14 & & - & & 86 & 7380 & 20.0425 & \\
\hline & 15 & & $\infty 0.10$ & & 87 & 7380 & 20.0226 & \\
\hline & 16 & & 00.50 & & 88 & 7390 & 2000127 & \\
\hline & 17 & & $01: 50$ & & 89 & 7390 & $20.00^{28}$ & \\
\hline & 18 & & $02: 40$ & & 90 & 7.400 & $19-5029$ & \\
\hline & 19 & & $03: 32$ & & 91 & $7: 40 \bigcirc$ & 10.5730 & \\
\hline & 20 & & $04: 23$ & & 92 & $7.41 \Omega$ & 19.6631 & 31 Days \\
\hline & 21 & & $06: 15$ & & 93 & $7.41(\Omega)$ & $10.55 \quad 1$ & \multirow{10}{*}{$\begin{array}{l}\text { Fourth Solar } \\
\text { Month Starts } \\
\text { A } \\
\text { U }\end{array}$} \\
\hline & 22 & & 00.08 & & 94 & 7.420 & 19.542 & \\
\hline & 23 & & $\infty 0.68$ & & 95 & $7: 420$ & 10.633 & \\
\hline & 24 & & 07.50 & & 96 & $7.43 \mathrm{O}$ & 19.514 & \\
\hline & 25 & & $08: 43$ & & 97 & $7.43 \bigcirc$ & 10.605 & \\
\hline & 26 & & 00.38 & & 98 & $7: 44 \mathrm{O}$ & 19.496 & \\
\hline & 27 & & 10.33 & & 99 & $7: 440$ & 19.487 & \\
\hline & 28 & & $11: 20$ & & 100 & $7: 45 \Omega$ & 19.478 & \\
\hline & 29 & & 1228 & & 101 & $7: 450$ & $10.45 \quad 9$ & \\
\hline & 30 & & 1322 & & 102 & $7: 46 \curvearrowright$ & 10.4410 & \\
\hline
\end{tabular}


5

\begin{tabular}{|c|c|c|c|c|c|c|c|}
\hline \multicolumn{8}{|c|}{ October * Year 2014} \\
\hline & Day & $\begin{array}{l}\text { Moon } \\
\text { Phase }\end{array}$ & Moonrise & \multirow{8}{*}{$\begin{array}{l}\text { Moonrise } \\
\text { Azimuth }\end{array}$} & Sunrise & \multirow{2}{*}{$\begin{array}{l}\text { Sunset } \\
10 \cdot 4311\end{array}$} & \multirow{8}{*}{$\begin{array}{l}\mathbf{A} \\
\mathbf{U}\end{array}$} \\
\hline & 1 & & 14:17 & & $1037: 46 \bigcirc$ & & \\
\hline & 2 & & 16:10 & & $1047: 47 \Omega$ & 19.4212 & \\
\hline & 3 & C & 15.60 & & $1057: 47 \Omega$ & $10-4113$ & \\
\hline & 4 & C & 16.46 & & $1067: 48 \Omega$ & $19 \cdot 3914$ & \\
\hline & 5 & C & 17.32 & & $107748 \mathrm{O}$ & 19.3815 & \\
\hline & 6 & C & 18. 15 & & $1087: 49$ & 19.3716 & \\
\hline \multirow{2}{*}{ Full Moon } & 7 & 0 & 18.68 & & 109740 & 1025617 & \\
\hline & 8 & $\theta$ & $19: 42$ & \multirow[t]{12}{*}{$81^{\circ}$} & $1107: 60 \Omega$ & 19:36 18 & \multirow{12}{*}{$\begin{array}{l}\text { Fourth } \\
\text { Solar } \\
\text { Month } \\
\text { Ends }\end{array}$} \\
\hline \multirow{11}{*}{$\begin{array}{l}\text { Fourth } \\
\text { Lunar } \\
\text { Month } \\
\text { Starts }\end{array}$} & 9 & & 20.26 & & $1117.51 \bigcirc$ & 19:3419 & \\
\hline & 10 & & 21:13 & & $1127.51 \mathrm{O}$ & $19: 3320$ & \\
\hline & 11 & & 2200 & & $113752 \Omega$ & 19:-3121 & \\
\hline & 12 & & 22.60 & & $114^{7.52} \mathrm{O}$ & 193022 & \\
\hline & 13 & & 23.41 & & $115^{7.63} \cap$ & 192923 & \\
\hline & 14 & & $\cdots$ & & $1167: 63$ & $18: 2824$ & \\
\hline & 15 & & $\infty 0-32$ & & $1177.54 \Omega$ & $1027^{25}$ & \\
\hline & 16 & & $01: 25$ & & $118755 \bigcirc$ & $10: 2826$ & \\
\hline & 17 & & $02: 16$ & & $1197.55 \bigcirc$ & 19.2527 & \\
\hline & 18 & & 0300 & & $120756 \mathrm{C}$ & 192428 & \\
\hline & 19 & & 00.60 & & $1217.56 \Omega$ & 19.2329 & \\
\hline & 20 & & 04.81 & & $122 \quad 7.57$ & 192230 & 30 DAYS \\
\hline & 21 & & $06: 43$ & & $1237: 68 \Omega$ & $19-211$ & $\begin{array}{l}\text { Fifth Solar } \\
\text { Month Starts }\end{array}$ \\
\hline & 22 & & 06.36 & & $1247.58 \Omega$ & $10: 202$ & \\
\hline & 23 & & $07: 30$ & & $1257.50 \mathrm{C}$ & $19: 193$ & \\
\hline & 24 & & 0820 & & $126: 00 \Omega$ & $19: 184$ & A \\
\hline & 25 & & 00.23 & & $127800 \Omega$ & $19: 175$ & $\underline{\mathbf{U}}$ \\
\hline & 26 & & 0021 & & 1287.010 & 18.166 & $\mathbf{T}$ \\
\hline & 27 & & 10.18 & & $1297.02 \bigcirc$ & 18.157 & $\mathbf{U}$ \\
\hline & 28 & & $11: 14$ & & $130 \quad 7.02 \Omega$ & $18: 148$ & $\mathbf{M}$ \\
\hline & 29 & & 12.07 & & $1311^{7.03} \Omega$ & 18:13 9 & $\mathbf{N}$ \\
\hline & 30 & & 12.67 & & $132704 \bigcirc$ & $18: 1210$ & \\
\hline & 31 & 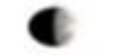 & $13: 44$ & & $133704 \Omega$ & 18:11 11 & \\
\hline
\end{tabular}




\section{6}

November * Year 2014 ?

\begin{tabular}{|c|c|c|c|c|c|c|c|}
\hline & Day & \multirow{2}{*}{$\begin{array}{l}\text { Moon } \\
\text { Phase }\end{array}$} & Moonrise & \multirow{6}{*}{$\begin{array}{c}\text { Moonrise } \\
\text { Azimuth }\end{array}$} & Sunrise & Sunset & \\
\hline & 1 & & $14: 27$ & & 1347.05 & $18: 11 \quad 12$ & \\
\hline & 2 & & 15.10 & & 1357.06 & $18.10 \quad 13$ & \\
\hline & 3 & & $15: 62$ & & $136^{7.07}$ & $18.09 \quad 14$ & \\
\hline & 4 & & 16.33 & & $137>07$ & $1808 \quad 15$ & \\
\hline & 5 & & $17: 17$ & & 1387.08 & 18.0816 & \\
\hline Full Moon & 6 & & 1801 & $75^{\circ}$ & 1397.00 & $18.07 \quad 17$ & \\
\hline Fifth & 7 & & 18.48 & & $1407: 10$ & $\begin{array}{ll}18.06 & 18\end{array}$ & \\
\hline Lunar & 8 & & 19.38 & & $1417: 10$ & $1805 \quad 19$ & \\
\hline Month & 9 & & 20.29 & & $1427: 11$ & $1805 \quad 20$ & \\
\hline Starts & 10 & & $21: 22$ & & $1437: 12$ & $18: 04 \quad 21$ & \\
\hline & 11 & & 22.14 & & $1447: 13$ & 18.0422 & \\
\hline & 12 & & 23.07 & & $145 \quad 7: 13$ & 18.0323 & \\
\hline & 13 & & 2350 & & $146 \quad 7: 14$ & 18.0224 & \\
\hline & 14 & & $\cdots$ & & $147 \quad 7: 16$ & $18.02 \quad 25$ & \\
\hline & 15 & & $\infty .50$ & & $1487: 16$ & 180126 & \\
\hline & 16 & & $01: 42$ & & $1497: 17$ & 18.0127 & Fift \\
\hline & 17 & & $02: 33$ & & $1507: 17$ & 18.0028 & \\
\hline & 18 & & 0326 & & $1517: 18$ & 180029 & \\
\hline & 19 & & $04: 18$ & & $152^{7: 19}$ & 17.6930 & \\
\hline & 20 & & $05: 15$ & & $153 \times 20$ & 17.5031 & 31 Days \\
\hline & 21 & & $06: 11$ & & 154721 & $1759 \quad 1$ & Sixth Solar \\
\hline & 22 & & 07:10 & & 155721 & $\begin{array}{cc}17: 68 & 2\end{array}$ & \\
\hline & 23 & & 0800 & & 156722 & $1758 \quad 3$ & \\
\hline & 24 & & 09.07 & & $157>23$ & $17.58 \quad 4$ & \\
\hline & 25 & & 10.02 & & $158 \quad 724$ & $17: 58 \quad 5$ & \\
\hline & 26 & & 10.55 & & $159 \quad 725$ & $17.57 \quad 6$ & \\
\hline & 27 & & $11: 43$ & & $160 \quad 7: 26$ & $17.67 \quad 7$ & \\
\hline & 28 & & 1228 & & 161726 & $17: 57 \quad 8$ & \\
\hline & 29 & & $13: 10$ & & 162727 & $17: 67 \quad 9$ & \\
\hline & 30 & & 13.61 & & 163728 & $17.57 \quad 10$ & \\
\hline
\end{tabular}




\section{7}

December - Year [2014 -

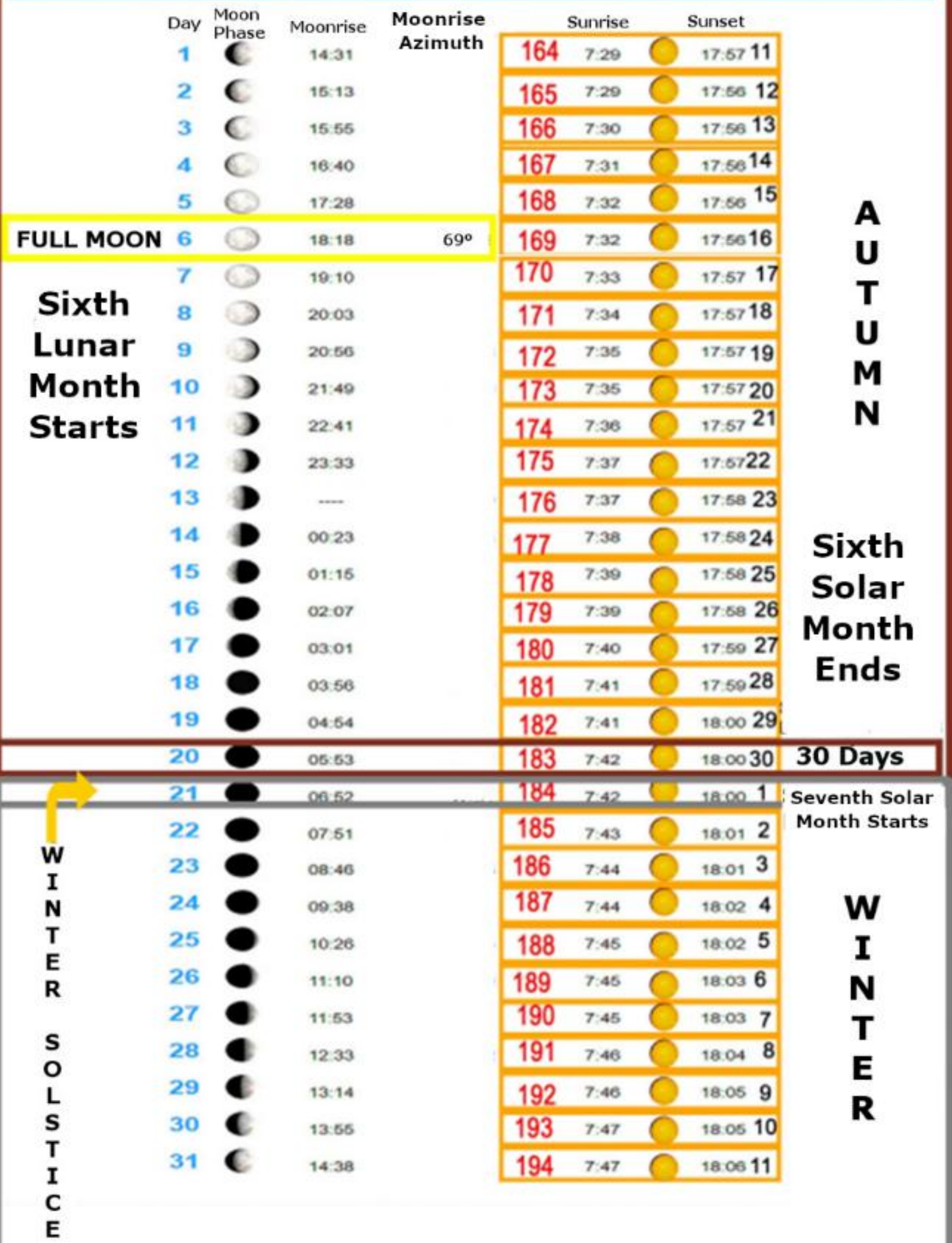




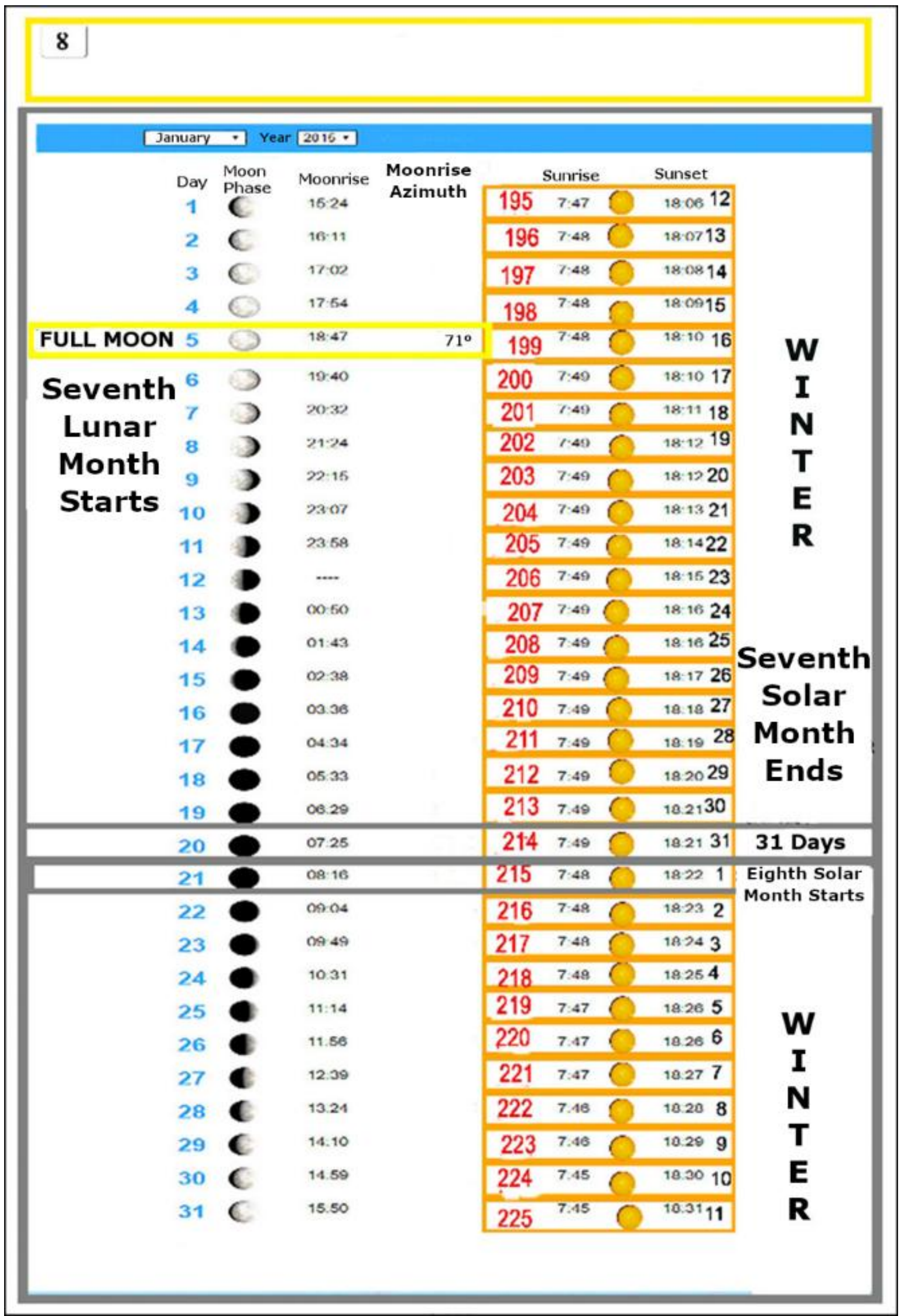




\section{9}

February - Year 2015 -

\begin{tabular}{|c|c|c|c|}
\hline & $\begin{array}{c}\text { Day } \\
1\end{array}$ & $\begin{array}{l}\text { Moon } \\
\text { Phase } \\
\text { C }\end{array}$ & $\begin{array}{c}\text { Moonrise } \\
16: 41\end{array}$ \\
\hline & 2 & & $17: 34$ \\
\hline FULL MOON & 3 & 0 & 18.26 \\
\hline & 4 & $\Theta$ & $19: 18$ \\
\hline
\end{tabular}

Eighth $5 \quad 2000$

$\begin{array}{lll}\text { Lunar } & 6 & 7101\end{array}$

$\begin{array}{llll}\text { Month } 7 & 7 & 7152\end{array}$

Starts 8 D 22:43

Moonrise
Azimuth

\begin{tabular}{|ccc}
\multicolumn{2}{c}{ Sunrise } & \multicolumn{1}{l}{ Sunset } \\
\hline 226 & $7: 44$ & $18: 3112$ \\
\hline 227 & $7: 44$ & $18: 3213$
\end{tabular}

$9^{2}$ 23:35

10 D -..

11 D 0028

1200123

130 02:19

$14 \bigcirc$ 03:16

15 04:12

$16 \bigcirc 05.07$

$17 \bigcirc 06.00$

$18 \bigcirc 06: 50$

$75^{\circ}$

\begin{tabular}{|llll|}
\hline 228 & $7: 43$ & & $18: 3314$ \\
\hline 229 & $7: 43$ & & $18: 3415$ \\
\hline
\end{tabular}

\begin{tabular}{|llll|}
\hline 229 & $7: 43 \bigcirc$ & $18: 3415$ \\
\hline 230 & $7: 42 \bigcirc$ & $18: 3516$ \\
\hline
\end{tabular}

W

$231^{7.42} \bigcirc{ }^{18.36} 17 \quad \mathbf{N}$

$2327: 41 \bigcirc \begin{aligned} & 18: 3618 \\ & 7\end{aligned}$

$2337.40 \bigcirc \quad 18.3719$

$2347: 40 \bigcirc \quad 18: 3820$

E

$2357: 39 \bigcirc \quad 18: 3921$

$\mathbf{R}$

$236^{7.38} \cap \quad 18: 4022$

$2^{737} \cap 1874023$

$238^{7: 37} \quad 18: 4124$

$239^{7: 36} 18.4225$

240 7:35 18.4326

Eighth

Solar

$241^{7: 34}{ }^{18.4327}$ Month

$\begin{array}{lll}242 & 7: 34 & 18.4428\end{array}$

$2437: 33 \bigcirc 18: 4529$

Ends

$19 \bigcirc 07: 38$

$20008-22$

$2447: 32 \bigcirc 18.4630$

$245 \quad 7: 31(18.4631$

31 DAYS

\begin{tabular}{|llll|}
\hline 246 & $7: 30$ & & $18: 47$ \\
\hline 247 & $7: 29$ & & 18.48 \\
\hline 248 & $7: 28$ & & $18: 49$ \\
\hline 249 & $7: 27$ & $\bigcirc$ & 18.49 \\
\hline 250 & $7: 26$ & $\bigcirc$ & $18: 50$ \\
\hline 251 & $7: 25$ & $\bigcirc$ & 18.51 \\
\hline 252 & $7: 24$ & $\bigcirc$ & 18.51 \\
\hline 253 & $7: 23$ & $\bigcirc$ & 18.52 \\
\hline
\end{tabular}

Ninth Solar

Month Starts

$22 \bigcirc 09.51$

23 10:36

$24 \bigcirc 1121$

251208

26 12.56

27 C $13: 47$

28 C 14:38

$\mathbf{R}$ 
10

March - Year 2016 -

Day Moon Moonrise Moonrise

1 C 15.30

2 C 16.22

$3 C_{17: 14}$

$4 \circlearrowright 1806$

FULL MOON

Ninth

Lunar

5

Month

Starts 10 23:1"

18.56

6
19.47

732038

8 21.31

9 2 22:23

Azimuth

\begin{tabular}{|c|c|c|}
\hline \multicolumn{2}{|c|}{ Sunrise } & Sunset \\
\hline 25 & 7.220 & 10.53 \\
\hline 255 & $7: 21 \bigcirc$ & 18.53 \\
\hline 25 & $7: 200$ & 18.54 \\
\hline 257 & $7: 19 \mathrm{C}$ & 1866 \\
\hline 25 & 7180 & 1865 \\
\hline
\end{tabular}

$259 \quad 7: 17 \bigcirc \quad 1868$

$260 \quad 7: 16 \bigcirc \quad 18.57$

$\begin{array}{llll}261 & 7.15 & 10.57\end{array}$

$\begin{array}{lll}262 & 7.14 & 18.58\end{array}$

$263 \quad$ r:13 $\bigcirc \quad 18.68$

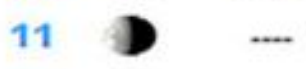

12 o: 11

13001.06

$14 \bigcirc 02.00$

$15 \bigcirc 02.51$

$16 \bigcirc 03: 46$

$17 \bigcirc 0436$

$18 \bigcirc 05 \cdot 24$

19

๑) 10

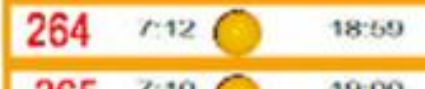

\begin{tabular}{lll}
\hline 265 & $7: 10$ & 10.00 \\
\hline 266 & 7.09 & 10.00
\end{tabular}

$267^{7.00} \mathrm{C}^{19.01}$ Ninth

$\begin{array}{llll}268 & 7.07 & 10.02 & \\ 2 & & \end{array}$

$\begin{array}{lllll}269 & 7.06 & 19.02\end{array}$

$270^{100} \mathrm{C}^{1903}$

Month

$271.7 .04 O^{1903}$

Ends

$2727.02 \bigcirc \quad 1904$

\begin{tabular}{|c|c|c|}
\hline $\mathbf{S}$ & 21 & 07.40 \\
\hline $\mathbf{P}$ & 22 & 08.21 \\
\hline $\mathbf{R}$ & 23 & $09: 11$ \\
\hline $\begin{array}{l}\mathbf{I} \\
\mathbf{N}\end{array}$ & 24 & $00 \div 60$ \\
\hline G & 25 & $10 \cdot 49$ \\
\hline & 26 & $11: 41$ \\
\hline E & 27 & 12.32 \\
\hline $\mathbf{Q}$ & 28 & 13.25 \\
\hline $\begin{array}{l}\mathbf{U} \\
\mathrm{T}\end{array}$ & 29 & $15: 17$ \\
\hline $\mathbf{N}$ & 30 & $16: 00$ \\
\hline 0 & 31 & $17-\infty$ \\
\hline
\end{tabular}

\begin{tabular}{|lll|l}
273 & 7.01 & 10.04 & 28 DAYS
\end{tabular}

$274700 \bigcirc 1905$

$\begin{array}{lll}275 & 6.59 & 19.06 \quad \text { Tenth Solar } \\ \text { Month Starts }\end{array}$

276 6:58 19.06

$277^{6: 51}(19: 0 /$
$278-650 \quad 1907$

\begin{tabular}{|lll}
\hline 279 & 6.54 & 19.08 \\
\hline 280 & 6.50 & 19.08 \\
\hline 281 & $6.52 \bigcirc$ & 19.00 \\
\hline 282 & $7.51 \bigcirc$ & $20: 10$ \\
\hline 283 & 7.49 & $20: 10$ \\
284 & 7.48 & 70.11 \\
\hline
\end{tabular}

S

P

R

I

N

G 
11

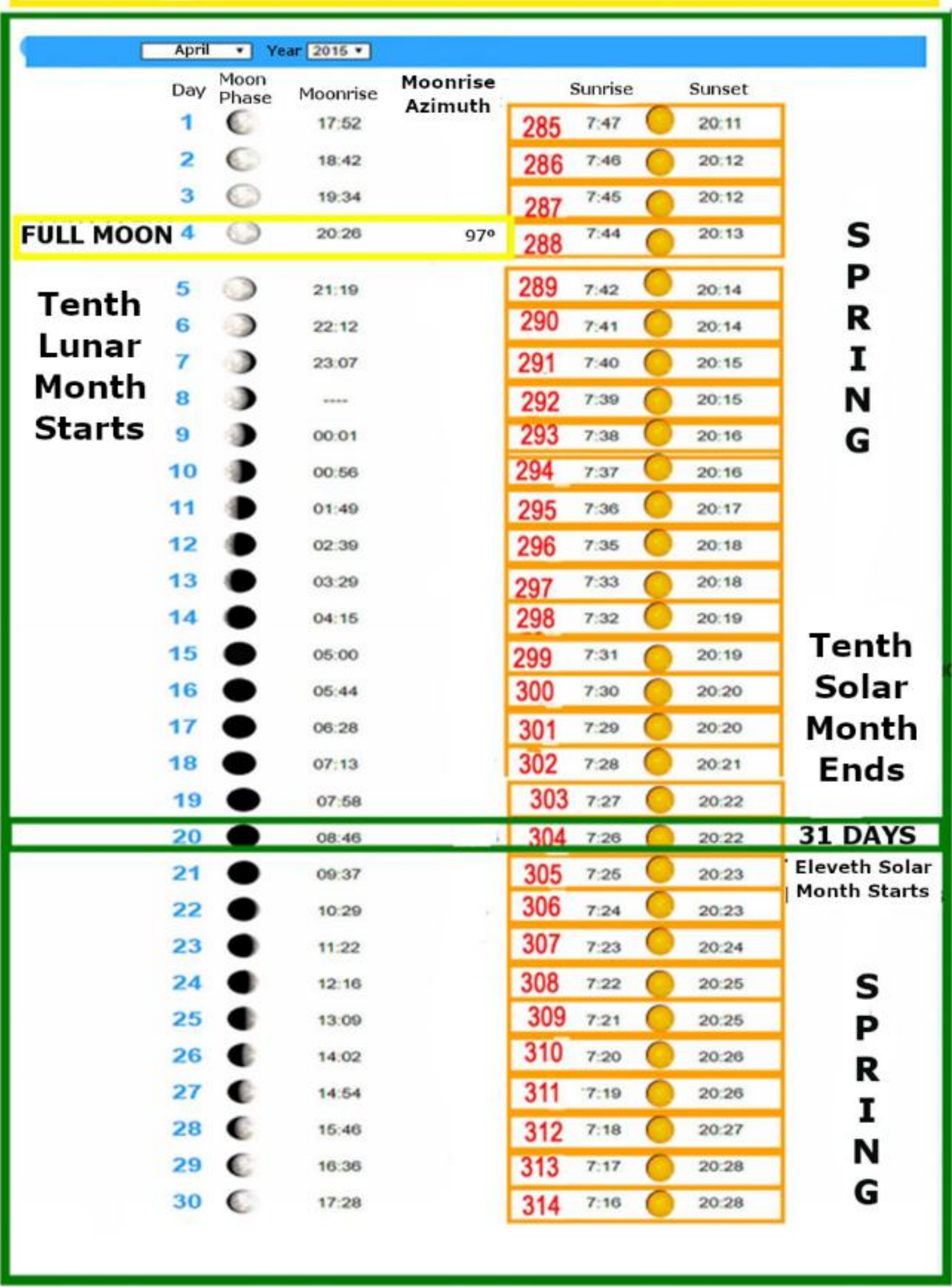


12

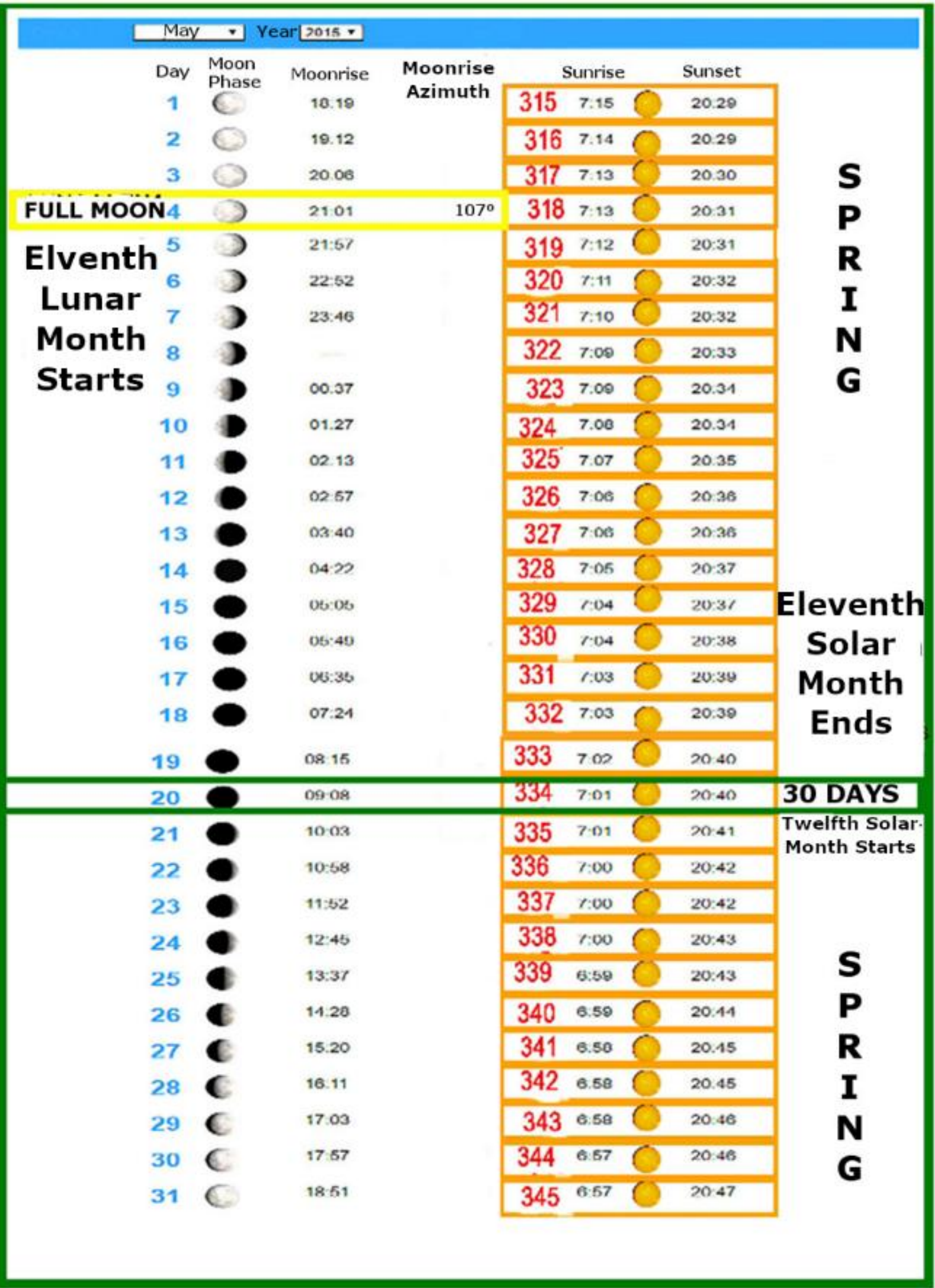


13

\begin{tabular}{|c|c|c|c|c|c|c|c|c|}
\hline \multirow[b]{4}{*}{ FÜLZL MOON } & June & -0 ye & $\operatorname{si} 20150$ & & & & & \\
\hline & \multirow{2}{*}{$\begin{array}{c}\text { Day } \\
1\end{array}$} & \multirow{2}{*}{$\begin{array}{l}\text { Moon } \\
\text { Phase }\end{array}$} & \multirow{2}{*}{$\begin{array}{c}\text { Moonrise } \\
19.48\end{array}$} & \multirow{2}{*}{$\begin{array}{l}\text { Moonrise } \\
\text { Azimuth }\end{array}$} & \multicolumn{2}{|c|}{ Sunrise } & \multirow{2}{*}{$\begin{array}{r}\text { Sunset } \\
20: 47\end{array}$} & \multirow{20}{*}{$\begin{array}{l}\text { Twelfth } \\
\text { Solar } \\
\text { Month } \\
\text { Ends }\end{array}$} \\
\hline & & & & & 346 & 6.57 & & \\
\hline & 2 & 3 & $20: 44$ & $111^{\circ}$ & 347 & 6.56 & $20: 48$ & \\
\hline \multirow{17}{*}{$\begin{array}{c}\text { Twelfth } \\
\text { Lunar } \\
\text { Month } \\
\text { Starts }\end{array}$} & 3 & & $21: 40$ & & 348 & 6.56 & $20: 48$ & \\
\hline & 4 & & 22.33 & & 349 & 6.56 & $20: 49$ & \\
\hline & 5 & & 23.25 & & 350 & 6.56 & $20: 49$ & \\
\hline & 6 & & - & & 351 & 6.56 & 20.50 & \\
\hline & 7 & & $00: 13$ & & 352 & 6.55 & 20.50 & \\
\hline & 8 & & 00.58 & & 353 & 6.55 & $20: 51$ & \\
\hline & 9 & & $01: 41$ & & 354 & .6 .55 & 20.51 & \\
\hline & 10 & & $02: 22$ & & 355 & 6.55 & 20.52 & \\
\hline & 11 & & 03.03 & & 356 & 6.55 & 20.52 & \\
\hline & 12 & & $03: 46$ & & 357 & 6.65 & 20.62 & \\
\hline & 13 & & $04: 29$ & & 358 & 6.55 & $20: 53$ & \\
\hline & 14 & & $05: 16$ & & 359 & 6.55 & 20.53 & \\
\hline & 15 & & 06.04 & & 360 & 6.55 & 20:54 & \\
\hline & 16 & & $06: 56$ & & 361 & 6.55 & 20.54 & \\
\hline & 17 & & 07:51 & & 362 & 6.55 & $20: 54$ & \\
\hline & 18 & & $08: 45$ & & 363 & 6.65 & 20.55 & \\
\hline & 19 & & $00: 41$ & & 364 & 6.56 & 20.55 & \\
\hline YEAR END & 20 & & 10.34 & & 365 & 6.56 & 20.55 & 31 DAYS \\
\hline $\mathbf{S}$ & 21 & & $11: 28$ & & & 6.56 & 20.55 & \\
\hline$\underset{M}{\mathbf{M}}$ & 22 & & 12:19 & & & 6.56 & 20.56 & \\
\hline$M$ & 23 & & 13:11 & & & 6.56 & $20: 56$ & \\
\hline $\begin{array}{l}E \\
R\end{array}$ & 24 & & $14: 02$ & & & 6.56 & 20.56 & \\
\hline k & 25 & & $14: 54$ & & & 6.67 & 20.56 & \\
\hline $\mathbf{S}$ & 26 & C & $15: 46$ & & & 6.57 & 20.56 & \\
\hline O & 27 & C & $16: 39$ & & & 6.57 & 20.57 & \\
\hline 5 & 28 & C & $17: 35$ & & & 6.58 & 20.57 & \\
\hline$T$ & 29 & C & $18: 31$ & & & 6.58 & $20: 57$ & \\
\hline $\begin{array}{l}\text { I } \\
\text { C }\end{array}$ & 30 & 0 & 19.28 & & & 6.58 & 20.57 & \\
\hline $\mathbf{E}$ & & & CIC & E IS R & EPI7 & ED & & \\
\hline
\end{tabular}


To cite this article:

Marcial Medina, Antonio Arnaiz-Villena. 2018. The Moon: in Prehistoric Lunisolar Rock Calendar "Quesera" -Cheeseboard- at Lanzarote, Canary Islands, Spain.

International Journal of Modern Anthropology. 2 (11): 182 - 212

DOI: http://dx.doi.org/10.4314/ijma.v2i11.9

\section{(2) $\odot \Theta \Theta$}

This article, as all articles published in this journal, is under The Creative Commons Attribution: Attribution-NonCommercial-NoDerivatives 4.0 International (CC BY-NC-ND 4.0).

https://creativecommons.org/licenses/by-nc-nd/4.0/ 